\title{
DIAMOND-BEARING IN THE NORTH OF EUROPEAN RUSSIA AND PROSPECTS OF NEW DIAMOND DEPOSITS DISCOVERY
}

\author{
V.S. Shchukin*, V.N. Nesis**, S.I.Trushin**, S.L. Roslyakov**, K.V. Efimov**, A.I. \\ Osetskiy**, E.V. Shchukina***. \\ *Proex Service Ltd, Arkhangelsk, Russia, vlad.shchukin@mail.ru \\ **Polymetal International Plc, St. Petersburg, Russia, , VNesis@polymetal.ru, trushin@polymetal.ru, \\ roslyakov@polymetal.ru, efimov@polymetal.ru, osetskiy@polymetal.ru. \\ $* * * \mathrm{~V}$. S. Sobolev Institute of Geology and Mineralogy SB RAS, Novosibirsk, Russia, \\ helenashchukina@gmail.com
}

\section{Introduction}

According to archival data the first diamond crystal within Russia territories was found in 1730 by a twelve-year old boy on the bank of the North Dvina river near Orletsy fortress in Arkhangelsk Region. It is most likely that the diamond was rather large as it was cut and sent to tsar court. Mikhail Lomonosov knew about this finding as he wrote in his famous treatise "About Earth Layers" the following: "...Orletsy mountains are able to bear diamonds" [5]. Almost 100 years later on July $4^{\text {th }}$ 1829 the second diamond crystal was found in the Urals gold placer deposits. While the diamond finding on the bank of the North Dvina was very soon forgotten and Lomonosov's ideas were not heard by the scientific world diamond findings in gold placers of Ural became regular which finally led to discovery of numerous placer diamond deposits. The first kimberlite rocks in the North of European Russia were found on the river Mela in Wintercoast diamondiferous area of Arkhangelsk Region in 1975. Furthermore, in 1980 the first diamondiferous kimberlite pipe Pomorskaya was discovered. These discoveries gave a start to the present stage of diamond exploration in the European North of Russia.

Prospecting work in Ural in the second half of the $20^{\text {th }}$ century led to the discovery of a few dozen of placer deposits of diamonds. Round shape (Ural or Brasilian diamond type) and high quality of crystals are the main distinguishing features of Ural diamonds. Success in prospecting work in Ural stimulated diamond search in Timan being for a long time considered as the Ural's branch. The first diamonds of the Northern Timan were found in alluvial sediments by geologist M. Apenko in 1953. By now diamonds and mineral indicators of kimberlites are identified in the Northern Timan in sediments of early Silurian, middle Devonian and modern alluvium. Fine crystals of diamond are found in dikes of lamprophyres[6]. In middle Timan three non-diamondiferous pipes were found while the diamonds were discovered in middle-late Devonian sediments and modern alluvium. Polymineral placer in Ichet-Yu (diamonds, gold, platinum, tantalum, niobates) in Devonian sediments was explored as well as single crystals of diamonds that were found in South Timan as well.

In 1975 kimberlite sills were detected on the river Mela on Belomoro-Kuloyskoe plateau (Wintercoast diamondiferous area) which led to prospecting work in this area followed by discovery of the first diamondiferous kimberlite pipe in 1980. Currently more than 70 pipes of different composition are discovered in Belomoro-Kuloyskoe plateau, 25 pipes among them are more or less diamondiferous and 6 pipes have industrial significance. Five pipes of Zolotitsa group form Lomonosov diamond deposit and one pipe makes up Grib diamond deposit. Both of these deposits are involved into the industrial development.

Significant increase of diamond prospecting in the North of the East-European platform caused the discovery of Ermakovsky field of low-grade diamondiferous kimberlites at the Kola Peninsula, kimberlites at Kimozero and numerous low-grade diamondiferous bodies of lamproites in Karelia [7]. 
Four fields of weakly diamondiferous kimberlites and lamproites are found in neighboring Finland $[1,2,3,4]$ Almost all territory of Northern European part of Russia from Finland boundary to Ural has findings of single crystals of diamonds in intermediate collectors and modern alluvium. (Figure 2). Analysis of diamond findings allocation on the area and section sedimentary cover of the platform indicates to multiplicity and wide age range of their original sources and points to high probability of new findings of diamondiferous areas and diamond deposits in the North of Russia.

It is well known that tectonic structure of a territory is crucial for possibilities of diamondiferous magmatism occurrence as well as for allocation of kimberlite fields and separate kimberlite pipes in the area. Therefore the more specific our knowledge about tectonic structure of a territory is especially its crystalline basement the more confident is our prognosis. Peculiar properties of crystalline basement of ancient platforms are very well reflected in magnetic fields, thus interpretation of magnetics susceptibility is very important for understanding of platform foundation structure.

650 maps sheets of 1:200 000 scale of aeromagnetic survey done in various years had been digitized, all sheets united in one project, mapped anomalous magnetic field $(\Delta \mathrm{T})$ and visualized the data. On the map obtained all main geological structures of crystalline basement including ancient cores of foundation - cratons and their moving belts are very well displayed. Besides, series of linear combined structures of North-Eastern, sub- meridional and sub-latitudinal spreadings are allocated. Linear structures of sub- meridional spreading controlling the location of diamondiferous magmatism of middle-late Devonian age are of the particular interest. While processing of large-scale survey data it is evident that such structures penetrate nearly all Northern part of the Russian plate (Figure 1).

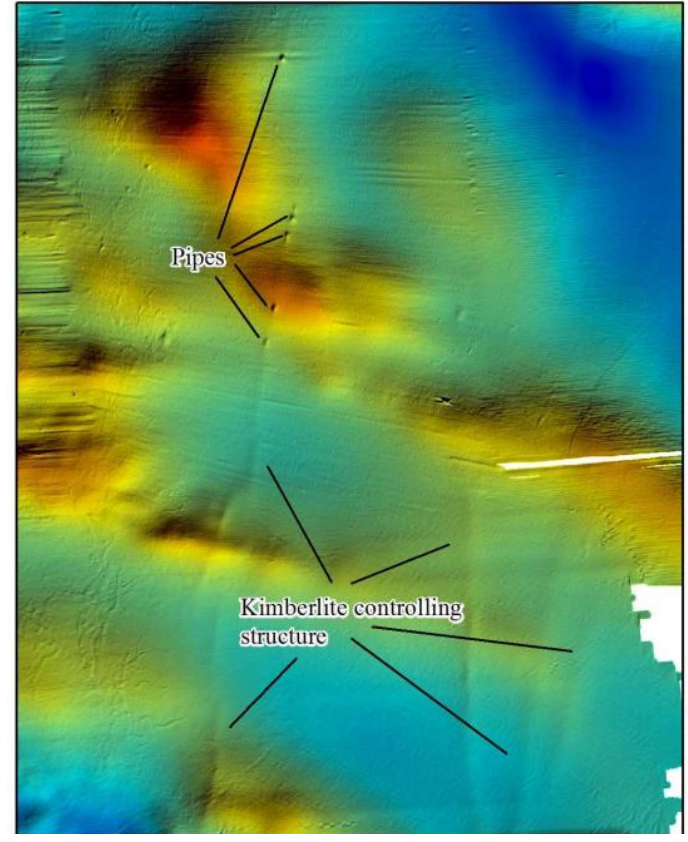

Figure 1. Example of kimberlite controlling structure based on large-scale airborne magnetic survey data.
Tectonic structure scheme of crystalline basement platform of the Northern European part of Russia was made up on basis of map of anomalous magnetic field $(\Delta \mathrm{T})$ with the usage of gravimeter and seismology data. Areas of kimberlite and assosiated magmatism, findings of diamonds and aggregations of mineral indicators of kimberlite in most cases refer to ancient cratons and median masses (Figure 2). Zones of dissection of ancient cratons and median masses by linear structures are of the greatest interest for further exploration of new diamondiferous areas and diamond deposits.

Thus, diamond exploration should be executed with careful consideration of wide age range of diamondiferous magmatism and must be focused within the bounds of ancient cratons and median masses. Findings of new diamondiferous magmatites aged from early Proterozoic to Mesozoic are possible within Murmansk and Karelian cratons. Exploration within Shenkursk, Sysolsky and Volga-Ural cratons should be focused on magmatites of Permian-Triassic age and younger. Murmansk and Karelian cratons are the most promising areas for discoveries of new diamond deposits of kimberlite and lamproite type at the moment. Moreover opportunities of Wintercoast diamondiferous area are not exhausted at all and our discovery of two new kimberlite pipes in 2016 can justify our concept. Eastern part of Arkhangelsk median mass where the diamond findings are allocated, fragments of kimberlite rocks and numerous mineral indicators of kimberlites have not been examined yet as well as original sources of Ural and Timan placer deposits. Thereby, 
all above mentioned facts demonstrate great opportunities to discover new diamondiferous areas and diamond deposits in the European North of Russia.

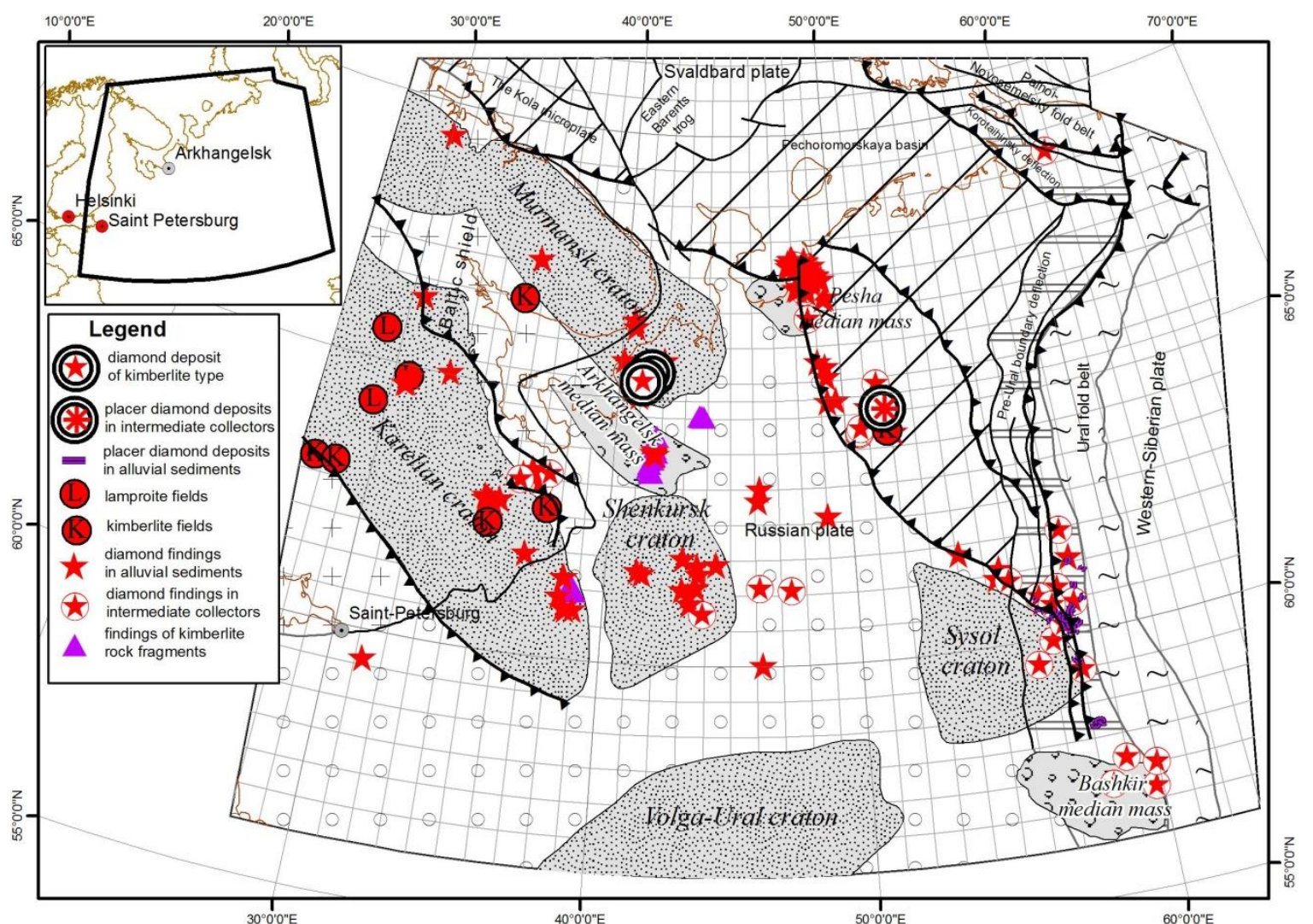

Figure 2. Tectonic scheme and diamond-bearing of the North European part of the East-European platform

\section{References}

1.H.E. O'Brien and M.Tuni. Mineralogy and geochemistry of kimberlites and related rocks from Finland. Proceedings of the VII International Kimberlite Conference . Volume 2. Cape Town. 1999. p.625-636

2.Hugh O'Brien, Marja Lehtonen, Roy Spencer fnd Andrew Birnie. " Lithospherc mantle in estern Finland: a $250 \mathrm{~km}$ 3D trasect" $8^{\text {th }}$ IKC, 2003.

3.O'Brien H., Bradley J. “ New kimberlite discoveries in Kuusamo, northen Finland. $9^{\text {th }}$ IKC. 2008. Extended Abstract A-0346.

4.Marja Lehtonen, Hugh O'Brien, Petri Peltonen, Bo Johanson and Lassi Parranen "Layered mantle at the EDGE of the Karelian craton: P-T of mantle xenocrysts and xenoliths from eastern Finland kimberlites" $8^{\text {th }}$ International Kimberlite Conference Long Abstract, 2003.

5.Lomonosov M. V. "About Earth Layers", St. Petersburg, 1763

6.Smirnov M. U. «Diamondiferous alkaline lamprophyres of Northern Timan». Documents of allRussian meeting «Diamonds. Diamond-bearing of Timan-Ural region», Syktyvkar, 2001, pages 5054.

7.Vladimir V. Ushkov, Victor N. Ustinov, Chris B. Smith, Galina P. Bulanova, Ludmila I. Lukyanova, Daphne de Vries, D.Graham Pearson. "Kimozero, Karelia; a diamondiferous Paleoproterozoic metamorphosed volcaniclastic kimberlite". $9^{\text {th }}$ International Kimberlite Conference Extended Abstract No 9IKC- A-00199, 2008. 